\title{
EU may help fund sarcophagus over Chernobyl remains
}

London. Nine years after the world's biggest known nuclear accident, the European Union (EU) is deliberating whether to contribute towards a US\$1.6-billion bill for sealing off the remains of Chernobyl reactor number four.

The EU has already funded a US\$4million feasibility study whose results were unveiled in the Ukrainian capital Kiev last week. This recommends stabilizing and dismantling the reactor's existing sarcophagus and covering the reactor's 100 tonnes of nuclear fuel and $400 \mathrm{~kg}$ of plutonium with an arch-shaped shelter.

The shelter would also cover hundreds of thousands of cubic metres of contaminated debris that will remain radioactive for about 10,000 years. But the project, which would take ten years to complete, has yet to find firm backers. The EU has not announced whether member states are prepared to commit further funds, while the Ukrainian government has said it is in no position to pay even part of the required costs.

The feasibility report was compiled by Alliance, a six-member multinational consortium of companies including Britain's AEA Technology, Walter Bau of Germany and SGN of France.

The report says that the reactor's lid and chimney are unstable and could collapse at any time, and warns of an additional hazard in the form of an earthquake. The region experiences earthquakes on average every 27 years of magnitude 5 on the Richter scale.

The Ukrainian government is believed to have appealed for US $\$ 4$ billion to pay for decommissioning all four Chernobyl reactors, as well as building three new power stations. But according to Greenpeace's Nuclear Research Unit, Ukraine would probably settle for US $\$ 2$ billion, but in the form of a grant rather than a repayable loan.

Kiev has so far received US\$933 million in grants for the Chernobyl plant and allied projects. Last July, an ECU100-million (\$133-million) grant was released under a EU scheme known as Technical Assistance to the Community of Independent States.

Additional sources of funds include ECU400 million in Euratom loans and a further US\$200 million in grants agreed at the Naples summit meeting of Group of Seven leaders in July last year to complete and upgrade the three new power stations to international safety levels.

Part of the money will also go towards shutting down and decommissioning Chernobyl's reactors numbers one and three by this year and 1998 respectively. The Ukranian president has said he is committed to closing reactors one, two and three by the year 2000 .

Pete O'Neill

\section{Nuclear waste programme under fire for 'incoherence'}

Paris. A 15-year programme set up by France in 1991 to explore options for the disposal of nuclear waste lacks a coherent research strategy and is already behind schedule. This is the conclusion of a commission set up to review the programme, whose report has fuelled demands from physicists outside the nuclear establishment for a greater role in developing new techniques for handling waste.

The nuclear waste programme was established by a law passed at the end of 1991 . This postponed a decision on what to do with waste from France's 55 nuclear reactors until 2006, in order to allow time for further research into three approaches for disposing of such waste.

One is to develop techniques for extracting and transmuting long-lived radioactive elements from waste. Another is to study conditions for storing low-level waste on the surface. The third requires the National Agency for Nuclear Waste both to choose candidate sites for storage of high-level nuclear wastes and to construct 'rock laboratories' at two of these locations.

In a report published earlier this month, a review commission made up of six experts nominated by the Senate and National Assembly says that research into the three approaches needs to be better coordinated by the various organizations and industrial groups involved, so that it can be treated in a "coherent and open" manner.

Its complaint represents more than a request for good housekeeping. Behind the call for better coordination appears to lie growing concern that the research programme risks being compromised by the influence of the French Atomic Energy Commission (CEA) in its choice of goals.

Claude Detraz, for example, head of the particle physics department at the Centre National de la Recherche Scientifique (CNRS), says that CEA suffers from a "culture" that is too orientated towards improving existing technologies and is "reluctant to explore to new areas". Research on nuclear waste disposal "cannot be left to CEA", he says.

\section{Baboon/man transplant backed for HIV victim}

San Francisco. Researchers seeking to use baboon bone marrow to restore the immune system of a patient with HIV have won the support of a key advisory panel to the Food and Drug Administration (FDA).

FDA officials had urged caution because of concern that xenotransplants, or crossspecies transfer of tissue and organ material, could stimulate the emergence of lethal new viruses into the human
Detraz's claims are implicitly supported by members of the commission, who argue that France's nuclear industry tends to restrict avenues of research to those that are compatible with existing processes.

Fundamental nuclear physics is not being given a sufficient role, they argue, pointing out the need for a broader approach that pays more attention to, for example, nuclear data, simulation techniques and models, high-intensity accelerators and materials.

In particular, both Detraz and the commission argue that more attention needs to be paid to alternative, long-term options for waste disposal, such as the transmutation of long-lived waste into shorter-lived elements.

Changing this situation requires giving CNRS a bigger role in the French programme, argues Detraz. He claims that CNRS offers a "different culture" from that of CEA, as well as greater "intellectual flexibility". He also points out that CNRS also has more nuclear physicists than CEA, whose staff are mainly engineers.

But although CNRS may have the competence to study such options, its annual budget for research into nuclear waste disposal is less than FF1 million. This sum pales beside that of CEA, which spent FF225 million last year just on a programme aimed at incinerating plutonium in fastbreeder reactors.

If the commission's recommendations are taken up by the government, CNRS may gain some ground. The most likely outcome, predict observers, is that the government will demand that CNRS and CEA, together with various other agencies involved, create a formal structure to coordinate their research on disposal.

The commission also argues that the "tightness" of the proposed research timetables means that the government may have to postpone any final decisions about waste disposal until after 2006. The government will reveal its reaction to the commission's recommendations in November when it presents a progress report on the waste disposal programme to the National Assembly.

Declan Butler population (see Nature 376,8 ; 1995).

But the FDA biological response modifiers advisory committee has now responded to the pleas of AIDS activists with a cautious endorsement. Members of the committee have asked for an improved consent form, a search for disease-free baboon donors and other safety measures such as tissue sample storage and monitoring of the patient for life. $\mathrm{S}$. $\mathrm{L}$. 